\title{
THE ECONOMIES SCALE OF AGRICULTURAL PRODUCT PROCESSING COMPANIES LISTED ON STOCK EXCHANGE IN HOCHIMINH CITY AND HANOI, VIETNAM
}

\author{
Le Thanh Tung, Pham Thi Quynh Nhu, Nguyen Hai An
}

\begin{abstract}
This studyappliedthe Cobb-Douglasproduction function to identify economicsefficiencyof 18 agricultural product processing companies listed on the Stock exchange in Ho Chi Minh City (HOSE) and Hanoi (HNX) in such sectors as fisheries, rubber and sugar in the period 20092013.The method employed FEM and REM models using panel data. The results showed that performance of all and each sector in this study has increasing returns to scale. In particular, firms in the sectors of fisheries and rubber primarily relied on raising capital to increase theiroutput value, while those in the sugar sectormainly increase labors toimprove their output value. Finally, the paper also provides some policy implications to improve the efficiency of capital and labor in the agricultural product processing companies.
\end{abstract}

Keywords: economics of scale, listed companies, agricultural processing companies

JEL Classification: J43, Q13

\section{INTRODUCTION}

According to the data from Vietnam General Statistics Office (GSO) in 2013, the agricultural sectorcontributed $18.4 \%$ to Vietnam's GDP. Besides, the agricultural industry provided jobs for 25.16 million employees (accounted for $46.9 \%$ of total labor force) and about 60.4 million people are living and working in rural areas (about $46.8 \%$ of total population). The role of agricultural industry is essential in the Vietnam economy. Therefore, the industrialization and modernization of agricultural and rural sector attracts a lot of attention. Particularly, the center of cohesion between industrialization and modernization is to connect and transform raw materials and outputs of agricultural sector to inputs of industrial sector. Thenceforth, the production value chain for agricultural product manufacturing and processing firms is formed to enhance the industrialization and modernization of agricultural industry in Vietnam.

Currently, for the case of agricultural product processing companies in Vietnam, the sectors of rubber, sugarcane and fisheriesplay the most important role. Thesecompaniesprovide goods not only for domestic market, but also for exportingmarkets such as USA, Japan, South Korea, China, Malaysia, India, etc.Due to theircharacteristics of production, the agricultural manufactories need to utilizelots of labors, capital and materials for increasing their outputs. However, their most common mistakes is to select outputs that causelabor shortage or surplus and utilize capital ineffectively that results in capital shortage. Therefore, it is essential and indispensable to conduct deeper study and analysis on effectiveness of input utilization (capital, labor) in production and business activitiesat companies.

This paper studied the economics scale of agricultural companies listed on HOSE and HNX from 2009 to 2013. The research used panel data regression with quarterly data. The research objective is to answer two question :(i) What kind of economics of scale for each sector and all sectors (ii) Does capital or labor determine the increase inoutputsof each sector and all sectors?Finally, thispaper also suggests some solutions to enhance the efficiency of management to better utilize capital and labor at agricultural product processing enterprises. 


\section{LITERATURE REVIEW AND MODEL RESEARCH}

The studies about economics of scale at levels offirms, regions or whole economy have been implemented in many countries in the world. Many types of production function have been proposed to illustrate the relationship between output and inputs, and the most common is Cobb-Douglasproduction function. The production function theory was developed by Charles Cobb and Paul Douglas (1928) after verification using the conditions of the US economy. The Cobb - Douglas production function stated thatoutput (Q) depends on labors (L) and capital $(\mathrm{K})$. In addition, the relationshipamong the variables of production functions is determined bylevel of science, technology andmanagement that are calledTotal Factor Productivity (TFP).

In recent decades, many studies have successfully applied Cobb - Douglas production function into economics of scale research in such fields as industry, trading and service. A study of Ingene and Lusch (1999) with the application ofCobb - Douglas function for trading sector in USA showed thatfor the case of allgrocery stores, return to scale remains constant while the small grocery storeshas increasedreturns to scale. Hossain et al. (2004) also studied returnsof scale for 21 sectors in Bangladesh. The results showed that only 14 sectors have increasingreturns of scaleswhile 7 sectors have diminishing returns of scale.Yuan et al. (2009) used Cobb-Douglas function in research of energy consumption in China, the result showed that improvement in technology declinesthe energy intensity of industrial sector by 6.3 percent per year. Hossain and Al-Amri (2010) also applied Cobb-Douglas function in Oman for 9 important sectors in industry. The research found that there are 7 sectors with increasing returns of scale and 2 sectors with decreasing returns of scale.

Based on Cobb-Douglas production function, the research model about economics of scale for the case of agricultural product processing company listed on HOSE and HNXwill be written as follows:

$$
Q_{\text {it }}=\mathbf{A} K_{i t}{ }^{\alpha} \mathbf{L i t}^{\beta}
$$

If $\alpha+\beta>1$, this production function has increasing returns to scale. $1 \%$ increase in inputs (labor, capital) results in more than $1 \%$ increase in outputs.

If $\alpha+\beta=1$, returns to scale of the function remains constant. If inputs (labor, capital) increase by $1 \%$, outputs increase by the same level of $1 \%$.

If $\alpha+\beta<1$, the function has diminishing returns to scale. If $1 \%$ increase in inputs (labor, capital) improves the outputs less than $1 \%$.

After transforming both sides of the equation(1) into logarithm form, we have the following equation (2):

$$
\begin{gathered}
\mathbf{L n Q}_{\mathbf{i t}}=\mathbf{\operatorname { l n } A}+\boldsymbol{\alpha} \ln K_{\mathbf{i t}}+\boldsymbol{\beta} \ln \mathbf{L}_{\mathbf{i t}}+\boldsymbol{\varepsilon}_{\mathbf{i t}} \\
\mathrm{i}=1,2,3 \ldots, \mathrm{n} \\
\mathrm{t}=1,2,3 \ldots, \mathrm{m}
\end{gathered}
$$

Where:Qis totaloutput of the sectors, Arepresents TFP, L is quantityof labor, andK isquantity of capital. $\alpha$ and $\beta$ denote the output elasticityon labor and capital respectively. When conducting regression model using panel data, $i$ denotes $\mathrm{i}^{\text {th }}$ firms $\left(i: 1 \rightarrow_{\mathrm{n}}\right)$ and $t$ denote time $(t: 1 \rightarrow \mathrm{m})$. 


\section{METHODOLOGY AND DATA}

\subsection{Econometrics method}

To accomplish the research objectives, thispaper appliespanel data regressionwith two methods of FEM and REM, and then usesthe Hausman test for selecting appropriatemethod.

According to Gujarati(2004) and Gujarati and Porter (2009), panel data regression model is written as following:

$$
Q_{i t}=\beta_{1}+\beta_{2} X_{2 i t}+\beta_{3} X_{3 i t}+\ldots+\beta_{k} X_{k i t}+u_{i t}
$$

Assume that the slope coefficients are unchanged across companies but intercepts vary across units. Thenceforth, model (3) can be rewrittenas follows:

$$
Q_{i t}=\beta_{1 i}+\beta_{2} X_{2 i t}+\beta_{3} X_{3 i t}+\ldots+\beta_{k} X_{k i t}+u_{i t}
$$

The differencein intercept may reflect the features of each company in terms of managerial philosophy or managerial style. Model (4) is known as the Fixed Effects Model (FEM). FEM is appropriate for the study using sample with short period.

In the Random Effects Model (REM), instead of treating $\beta_{1 \mathrm{i}}$ as fixed, we assume that it is a random variable with a mean value of $\beta_{1}$ (without $i$ denotation). The intercept for a specificcompany can be represented as follows:

$$
\beta_{1 i}=\beta_{1}+\varepsilon i ; \quad i=1,2, \ldots, N
$$

Where, $\varepsilon_{i}$ is a random error term with a mean value of zero and variance $\sigma_{\varepsilon}^{2}$.

It can be understood thatthe companies in the sample are derived from a larger sample setand have a common mean of intercept $\left(\beta_{1}\right)$. The individual difference in intercept valueof each company is reflected via the error term $\varepsilon_{i}$.

Substituting equation (5) into equation (4), we obtain:

$$
\begin{aligned}
& Q_{i t}=\beta_{1}+\beta_{2} X_{2 i t}+\beta_{3} X_{3 i t}+\ldots+\beta_{k} X_{k i t}+\varepsilon_{i}+u_{i t} \\
& Q_{i t}=\beta_{1}+\beta_{2} X_{2 i t}+\beta_{3} X_{3 i t}+\ldots+\beta_{k} X_{k i t}+w_{i t}
\end{aligned}
$$

Where:

$$
\mathbf{W i t}_{\mathbf{i}}=\boldsymbol{\varepsilon}_{\mathrm{i}}+\mathbf{u}_{\mathrm{it}}
$$

The equation (7) is called Random Effects Model (REM). The composite error term witis constituted of two components: $\varepsilon_{\mathrm{i}}$ denotes the cross-section or individual-specific error term, and $\mathrm{u}_{\mathrm{it}}$ denotes the combined time series and cross-section error term.

\subsection{Data}

The study used quarterly data for the period from the first quarter in 2009 to the end of fourth quarter in 2013. Each company has the number of observationsof 20 quarters. Data are derived from transparent reports, quarterly and yearly audited financial reports. The samples were surveyed at 9 fisheryfirms, 5 rubber firms and 4 sugar firms listed on HOSE and HNX.Total observations is 360 (20periods multiplied by18 firms). When conducting the research model, all data aretransformed to nature logarithm form. 
Tab. 1 - List of enterprises use statistical research data. Source: Research data from HOSE and HNX

\begin{tabular}{|c|l|c|c|c|}
\hline No & \multicolumn{1}{|c|}{ Name } & Listed & Field & $\begin{array}{c}\text { Stock } \\
\text { Code }\end{array}$ \\
\hline 1 & $\begin{array}{l}\text { Cuu Long An Giang Fisheries Import Export Joint } \\
\text { Stock Company }\end{array}$ & HOSE & Fisheries & ACL \\
\hline 2 & An Giang Fisheries Import and Export JSC & HOSE & Fisheries & AGF \\
\hline 3 & Nam Viet Joint Stock Company & HOSE & Fisheries & ANV \\
\hline 4 & NTACO Joint Stock Company & HOSE & Fisheries & ATA \\
\hline 5 & Basa Joint Stock Company & HOSE & Fisheries & BAS \\
\hline 6 & Number 4 Fisheries Join Stock Company & HOSE & Fisheries & TS4 \\
\hline 7 & Vinh Hoan Join Stock Company & HOSE & Fisheries & VHC \\
\hline 8 & Bac Lieu Fisheries Join Stock Company & HNX & Fisheries & BLF \\
\hline 9 & Number 1 Fisheries Join Stock Company & HNX & Fisheries & SJ1 \\
\hline 10 & Hoa Binh Join Stock Company & HOSE & Rubber & HRC \\
\hline 11 & Dong Phu Rubber JSC & HOSE & Rubber & DPR \\
\hline 12 & Phuoc Hoa Rubber JSC & HOSE & Rubber & PHR \\
\hline 13 & Thong Nhat Rubber JSC & HOSE & Rubber & TNC \\
\hline 14 & Tay Ninh Rubber JSC & HOSE & Rubber & SRC \\
\hline 15 & Bien Hoa Sugarcane JSC & BHS \\
\hline 16 & Lam Son Sugarcane JSC & HOSE & Sugarcane & LSS \\
\hline 17 & Thanh Thanh Cong Tay Ninh Sugarcane JSC & HBT \\
\hline 18 & KonTum Sugarcane JSC & Sugarcane & KTS \\
\hline
\end{tabular}

\section{RESULTS AND DISCUSSION}

\subsection{Firms' Returns to Scale by sectors}

This sectionestimatesfirms' returns to scale by sectors for the case of 9 fishery companies (180 observations), 5 rubber companies (100 observations) and 4 sugarcane companies (80 observations). Regression methods with panel data are employed using FEM and REM model. The regression results are presented as follows.

Tab. 2 - Regression Results by Sectors (Fishery - Rubber - Sugarcane)

\begin{tabular}{|c|c|c|c|c|c|c|}
\hline \multirow{3}{*}{ Variables } & \multicolumn{6}{|c|}{ Dependent variable: LnQ } \\
\hline & \multicolumn{2}{|c|}{ Fishery Branch } & \multicolumn{2}{|c|}{ Rubber Branch } & \multicolumn{2}{|c|}{ Sugarcane Branch } \\
\hline & FEM & REM & FEM & REM & FEM & REM \\
\hline $\mathrm{C}$ & $-1.351^{*}$ & $-1.569^{*}$ & 0.952 & 0.340 & 1.112 & 0.844 \\
\hline LnL & $0.524^{* *}$ & $0.479 * *$ & $0.540 * *$ & $0,432 * *$ & $0.876^{* *}$ & $0.480 * *$ \\
\hline LnK & $0.764 * *$ & $0.806^{* *}$ & $0.521^{* *}$ & $0.628 * *$ & $0.408^{* *}$ & $0.766^{* *}$ \\
\hline $\mathrm{R}^{2}$ & 0.859 & 0.850 & 0.877 & 0.812 & 0,822432 & 0.691 \\
\hline Adjusted $\mathrm{R}^{2}$ & 0.840 & 0.848 & 0.843 & 0.808 & 0,758140 & 0.683 \\
\hline F-statistics & 45.718 & 501.498 & 26.385 & 209.589 & 1279218.000 & 85.950 \\
\hline Probability & 0.000 & 0.000 & 0.000 & 0.000 & 0.000 & 0.000 \\
\hline $\begin{array}{c}\text { Hausman } \\
\text { test }\end{array}$ & \multicolumn{2}{|c|}{0.301} & \multicolumn{2}{|c|}{0.167} & \multicolumn{2}{|l|}{0.005} \\
\hline Observations & \multicolumn{2}{|c|}{180} & \multicolumn{2}{|c|}{100} & \multicolumn{2}{|l|}{80} \\
\hline
\end{tabular}

Note: ** and *:significant at $1 \%$ and $5 \%$ respectively 
After conducting regression analysis for each sector, Hausman test is also applied to determine whether FEM or REM is appropriate. Table 2 shows that P-value of fishery firms equals to0.301 and that of rubber branch is 0.167 ; that is, these values are more than 0.05 . Therefore, for the case of fishery and rubber sectors, REM is more suitable than FEM. In contrast, the Hausman test for sugarcane sector with P-value $=0.005<0.05$ indicates that FEM is more appropriate than REM.

Tab. 3 - Results of Production Function by sectors (Fishery - Rubber - Sugarcane)

\begin{tabular}{|l|l|c|}
\hline Industry & Production function using equation (2) & Production function using equation (1) \\
\hline Fishery & $\mathrm{LnQ}=-1.569+0.807 \mathrm{LnK}+0.479 \mathrm{LnL}$ & $\mathrm{Q}=0.208 \mathrm{~K}^{0.807} \mathrm{~L}^{0.479}$ \\
\hline Rubber & $\mathrm{LnQ}=0.34+0.629 \mathrm{LnK}+0.433 \mathrm{LnL}$ & $\mathrm{Q}=1.405 \mathrm{~K}^{0.629} \mathrm{~L}^{0.433}$ \\
\hline Sugarcane & $\mathrm{LnQ}=1.112+0.408 \mathrm{LnK}+0.876 \mathrm{LnL}$ & $\mathrm{Q}=3.089 \mathrm{~K}^{0.408} \mathrm{~L}^{0.876}$ \\
\hline
\end{tabular}

Table 3 shows that all the three sectorshave increasing returns to scale with $(\alpha+\beta)>1$. In particular, the value of fishery industry, rubber industry and sugarcane is 1.286, 1.061 and 1.285 respectively. The rubber enterprises have the lowest increasing returns to scale. The results also shows that the production function of fishery and rubber industries has contribution of capital higher than that of labor (due to the coefficient $\alpha>\beta$ ). On the other hand, the contribution of labor toward output in sugarcane industry is larger than that of capital (due $\alpha<\beta$ ). Additionally, in terms of Total Factor Productivity (TFP), the sugarcane industry was the highest (3.089), followed by the rubber industry (1.405) and the fishery industry (0.208).

\subsection{Returns to scale of all firms in threesectors: Fishery, Rubber and Sugarcane}

18 enterprisesin all three sectors with 360 observations are used for calculating returns to scale. Results from panel data regression method using FEM and REM are presented in Table 4.

Tab. 4 - Regression results of all firms in three sectors

\begin{tabular}{|c|c|c|c|c|}
\hline \multicolumn{3}{|c|}{ Dependent variable: LnQ } \\
\hline \multirow{2}{*}{ Variable } & \multicolumn{2}{|c|}{ FEM } & \multicolumn{2}{c|}{ REM } \\
\cline { 2 - 5 } & Coefficient & t-statistics & Coefficient & t-statistics \\
\hline $\mathrm{C}$ & $-1.759^{* *}$ & -3.181 & $-1.719^{* *}$ & -3.198 \\
LnL & $0.167^{*}$ & 2.566 & $0.171^{* *}$ & 2.655 \\
LnK & $0.937^{* *}$ & 16.727 & $0.932^{* *}$ & 17.297 \\
\hline $\mathrm{R}^{2}$ & 0.670 & 0.653 \\
Adjusted $\mathrm{R}^{2}$ & 0.650 & 0.651 \\
F-statistics & 32.699 & 336.135 \\
Probability & 0.000 & 0.000 \\
\hline Hausman test & \multicolumn{3}{|c|}{0.3017} \\
\hline Observation & \multicolumn{2}{|c|}{360} \\
\hline
\end{tabular}

Note: $* *$ and $*$ : significant at $1 \%$ and $5 \%$ respectively 
The result of the Hausman test indicates that REM is better than FEM with p-value of 0.3017 . From Table 4, the production function for the case ofall firms in three sectors is written as follows:

$$
\begin{gathered}
\operatorname{Ln} Q=-1.719+0.171 \operatorname{Ln} L+0.932 \operatorname{LnK} \\
Q=0.839 K^{0.932} L^{0.171}
\end{gathered}
$$

The results indicates that for the case of all firms in three sectors, there exists increasing returns to scale with the value of $(\alpha+\beta)$ higher than $1(\alpha+\beta=1.103)$. The coefficient of $\alpha=$ 0.932 is higher than $\beta=0.171$, which indicates that the increase in output is mainly due to capital while the contribution of labor is limited. The value of Total Factor Productivity (TFP) equal to 0.839 reflects the contribution of technology and management to the firms' outputs in all three sectors.

\section{CONCLUSION AND POLICY IMPLICATIONS}

This research applied panel data regression methodusing FEM and REM to estimate production function for the enterpriseslisted on HOSE and HNXin three sectors including fishery, rubber and sugarcane in the period of 2009-2013.Generally, this paper has contributed to the existing theoretical framework literature in twomainways: (1) it providedan experimentalevidence about the operation of firms in Vietnam, an emerging economy in Asia; (2)it alsosupplied some useful policy implications in SMEs area in developing countries.

In particular, the research results indicate that the enterprises in three sectors and each sector have increasing returns to scale. It is also found that the fishery and rubber sectors primarily rely on the increase in capital to improvethe quantity of outputs while the sugarcane sector mainly uses morelabours to increase output value.

Therefore, the results partly shows that the growth pattern of Vietnamese enterprises in the period of $2009-2013$ is chiefly dependent on capital leverage. Therefore,when the government decided tocontractionarymonetary policy, raise interest rates, reduce money supply and credit growth in this period immediately, a lot of enterprises havedifficulties in their production activities. This is considered as an obvious evidence for the growth model that primarily relies on credit and banking system in Vietnam in the past period.

From the findings, this research proposes some policy implicationsto improve production and business management in the future:

Firstly:Because Vietnam has abundant labor force,the enterprises need to focus onlaborintensive production to boost up their output. Furthermore, firms should pay special attention to labor productivity factor to increase the contribution of labor to firms' output. Firms should organize training, retraining and advanced training activities to improve qualification and skills, as well as arrange andutilizelabors for appropriate jobs.

Secondly:Firms should continuously invest ininnovation, technology improvements to increasethe contribution of science and technology tooutputs. Moreover, the advanced methods of production methods and organization should be actively applied to improve outputs value. Additionally, the connection between enterprises and the agricultural sector should be tighten to diversify processing products in order to construct a strong value chain in processing agricultural products industryfor domestic consumption and export.

Thirdly:Capital-intensive production model should be adjusted into model with harmonious combination of labor and capital; thenceforth, the effect of diminishing marginal productivity of capital can be inhibited. Moreover, firms need to be lessreliantoncapital to reduce the dependence on banks' creditgrowthand the increase in theeconomy's money supply. 
Fourth: The policy makers need to establish medium- and long-term development orientations and plansfor firms in each sector and the whole economy. Besides, the management agencies in each sector should also provide consultancy for firms on an appropriate specific model. On that basis, firms willconstruct their production and business plans to take best advantage of inputs, thereby enhance their competitiveness in the market, create more jobs as well as contribute to economic growth in the future.

On the other hand, this study also had limitations too among them followings can be mentioned: the research sample isquite small because there are only 18 firms in three sectors in agricultural in Vietnam and the study period only is from 2009 to 2013. The future study might develop more by adding more companies in these sectors in Vietnam and take data in longer period to make this topic be more better.

\section{References:}

1. Cobb, C. W., \& Douglas, P. H. (1928). A Theory of Production, American Economic Review, 18(1), 139-165.

2. Gujarati, D. N. (2004) Basic Econometrics (Fourth Edition), McGraw-Hill, USA.

3. Gujarati, D. N., \& Porter, D. C. (2009). Basic Econometrics (Fifth Edition), McGraw-Hill, USA.

4. Hajkova, D., \& Hurnik. J. (2007). Cobb-Douglas Production Function: The Case of a Converging Economy, Czech Journal of Economics and Finance, 57, 465-476.

5. Hossain, M. Z., Bhatti, M., \& Ali. Z. (2004). An econometric analysis of some major manufacturing industries: A case study, Managerial Auditing Journal, 19(6), 790795. DOI: http://dx.doi.org/10.1108/02686900410543895

6. Hossain, M. Z., \& Al-Amri, K. S. (2010). Use of Cobb-Douglas Production Model on Some Selected Manufacturing Industries in Oman, Education, Business and Society: Contemporary Middle Eastern Issues, 3(2), 78-80.

7. Hossain, M. Z., Majumder, A., \& Basak. T. (2012). An Application of Non-Linear Cobb-Douglas Production Function to Selected Manufacturing Industries in Bangladesh, Open Journal of Statistics, 2, 460-468.

8. Ingene, C. A., \& Lusch, R. F. (1999). Estimation of a department store production function, International Journal of Physical Distribution \& Logistics Management, 29 (7), 453 - 465. DOI: http://dx.doi.org/10.1108/09600039910371138

9. Moumtain, D. C. (1989). A Quadratic quasi Cobb-Douglas extension of the multiinput CES formulation, European Economic Review, 33, 143-158. DOI: http://dx.doi.org/10.1016/0014-2921(89)90042-1

10. Muro, K. (2013). A note on the three-sector Cobb-Douglas GDP funtion, Economic Modelling, Vol. 31, 18-21. DOI: http://dx.doi.org/10.1016/j.econmod.2012.11.008

11. Wei, T. (2007). Impact of energy efficiency gains on output and energy use with Cobb-Douglas production function, Energy Policy, 35, 2023-2030.

12. Yuan, C., Liu, S., \& Wu, J. (2009). Research on energy-saving effect of technological progress based on Cobb-Douglas production function, Energy Policy, 37(8), 2842-2846. DOI: http://dx.doi.org/10.1016/j.enpol.2009.04.025 


\section{Contact information}

Name: Le Thanh Tung

Diploma: Ph.D in Economics

Expertise: Economics, Economics Policy Analysis

Affiliation (University): Ton Duc Thang Universtity (Faculty of Business Adminstration)

Address: No 19 Nguyen Huu Tho street, Tan Phong ward, district 7, Ho Chi Minh city

Vietnam

Email: lethanhtung@tdt.edu.vn

Tel: 0918796756

Name: Pham Thi Quynh Nhu

Diploma: MBA

Expertise:Business Administration, International Economics

Affiliation (University): Ton Duc Thang Universtity (Faculty of Business Adminstration)

Address: No 19 Nguyen Huu Tho street, Tan Phong ward, district 7, HoChiMinh city

Vietnam

Email: phamthiquynhnhu@tdt.edu.vn

Tel: 0937962211

Name: Nguyen Hai An

Diploma: MBA

Expertise: Business Administration 